\title{
Black-ish Missiology: A Critique of Mission Studies and Appeal for Inclusion in the United States Context
}

\author{
Dwight A. Radcliff Jr. \\ Assistant Professor, Fuller Theological Seminary, Pasadena, CA, USA \\ dradcliff@fuller.edu
}

\begin{abstract}
Using the idiomatic expression found in the United States, this essay contends that the current field of missiology is black-ish. The expression is used to describe something purports to be Black (African American), but upon close inspection may not be authentic to the culture. This essay seeks to examine the dearth of specifically African American contributions to missiology. Citing issues of internal structuring and epistemology, an argument is made that African American voices and culture are often lost in this maze constituted by a lack of uniformity within mission studies. Additionally, there is an existing catalogue of Black scholarship that deals, directly and indirectly, with mission but is often not given the same latitude of inclusion and review that White scholarship is afforded in the United States.
\end{abstract}

\section{Keywords}

Black - Black-ish - missiology - African American - United States - mission culture - critique

This essay seeks to examine, briefly, the dearth of specifically African American contributions to the field of mission studies, or missiology, in the United States of America. ${ }^{1}$ Like many disciplines today, there is a lack of

1 There is still some discussion regarding whether missiology is indeed a discipline or a field of study (Farrell 2018). Because missiology is multi-disciplinary in nature and does not necessarily have its own set of methods - rather, it uses those of the disciplines it engages - some 
scholarly contributions made by African Americans in this field. Unlike many disciplines, mission studies (or missiology) has developed relatively recently, and it boasts an interdisciplinary approach. Missiology can trace its earliest roots back at least to the pioneering work of German scholar Gustav Warneck, beginning in 1892 (Sunquist 2013:5). ${ }^{2}$ However, the discipline did not truly gain traction and focus until well into the twentieth century. In comparison with sociology, philosophy, and theology, missiology is indeed a recent field.

Regarding the scarcity of African American contributions, it seems there are at least two key contributing factors. First, there is the discipline's internal structuring and epistemology. The current categorization subsumes major characteristics of the African American experience without giving unique space to these voices. Further, the lack of a single, clear, and concise direction for the discipline - or field of study - allows scholars and groups to insert their own direction for the discipline. This, necessarily, highlights certain types of work that are congruent with the dominate epistemology at play and ignores those that are conflicting. The second factor is that the discipline has largely failed to acknowledge the catalogue of existing African American scholarship that deals with missional (or missiological) themes, concepts, and terminology.

This essay does not purport to know or chronicle motives regarding the missing African American contributions; rather, it seeks to bring attention to the existing condition and suggest particular works for consideration. ${ }^{3}$ Nor does this essay assume complete knowledge of every missiological publication.

argue that it should be considered a field of study rather than a discipline. This aspect is mentioned for the sake of clarity. There is also much debate surrounding the true nature of missiology. "There is some confusion as to whether missiology is basically a practical science that helps missionaries prepare for their work, or whether it is a historical science that reveals a different dimension of church history, or whether it is a theological discipline that broadens or realigns theological studies" (Sunquist 2013:1). The American Society of Missiology (ASM) seems to be consistent in using the language of "discipline," although Shenk's (2014) history of the ASM uses both terms. Additionally, Skreslet's ASm monograph defines missiology as "the systematic study of all aspects of mission" (2012:195). I acknowledge the ramifications of these discussions yet affirm that this falls slightly outside the purview of this essay. The focus here is the lack of African American contributions and not the classification of the field. Hence, this essay will use both terms - discipline and field of study - interchangeably. This essay will engage this argument only insofar as it impacts the lack of African American scholarship in the field.

2 The work of Alexander Duff and Joseph Schmidlin should also be noted.

3 For work chronicling motives, dismantling oppressive structures that deliberately blocked non-White voices and scholarship, and demonstrating the pervasiveness of Whiteness as standard, see J. Kameron Carter (2008), Willie James Jennings (2010; 2017), Robert Hood (1990), and Sechrest et al. (2018). 
However, the works referenced represent graduate and doctoral studies in missiology, which included reviewing years of journal publications and searching missiological syllabi locally and online for courses taught in the United States. With these caveats, the conspicuous assertions stand; the discipline does not appear to be an inviting place for African American scholarship.

This essay speaks from a very specific context in hopes of addressing a particular lacuna within the larger context. Addressing this very specific context of African American contributions to missiology does not deny, ignore, or mute other contributions from other African Diasporic contexts - or even other African Diasporic contexts in America. Delroy Reid-Salmon critiqued Black theological discourse for omitting the "Caribbean Diasporan experience" (2008). Part of Reid-Salmon's critique is that Black theology had not even considered the Caribbean context as an, "appropriate starting point for theological inquiry" (2008:154). He goes on to discuss the omission of African Caribbean immigrant experiences in America. This essay affirms all human contexts as logical and necessary starting points for theological inquiry.

Adding to the fray, Robert Beckford sagaciously details the complexity of the Black experience and the difficulty of terminology. He notes that all such terms, "... emerge from particular situations and tend to be biased" (2000:1). For instance, Beckford's definition of Black, in his work in the United Kingdom, includes people of Asian descent and particular political alliances. In the United States, this would not be the case.

While African Americans do not maintain a monopoly on the Black experience, they are indeed part of the larger tapestry of that diasporic experience. To present one segment of that experience, neither silences nor invalidates other realities within the African Diaspora. The purpose of this essay is to highlight a very particular issue from the author's context, not to participate in any form of hegemony that omits other Black contexts. To the contrary, this work seeks to inspire and bring attention to work from other specific contexts, just as Reid-Salmon (2008), Noel Erskine (1981), and Anthony Reddie (2006; 2009) have done with Black theology globally.

There are global implications for this work as many contexts in our world are yet grappling with the reverberations of colonialism, various forms of slavery, and highly racialized societies that continue to marginalize and oppress the Black experience internationally. Often, in scholarly endeavors, the particular experience is sacrificed on the altar of the globalized context. However, particular contexts are where people live, and these particular contexts can speak volumes to the global context - challenging individuals and societies to hear voices that are frequently muted. 
As stated in the introduction, this essay asserts that missiology done specifically by, in, and on African American contexts is scarce. ${ }^{4}$ This is not to say that there are not any particularly African American contributions. To make such a claim would be both false and an affront to the tireless work of scholars in the field. Rather, the assertion is that there is a blatant dearth of these contributions - and even an avoidance of them in the existing literature. The African American narrative has experienced (and is experiencing) formidable issues such as racism, systemic injustice, classism, poverty, oppression, urbanization, cultural appropriation, and more. ${ }^{5}$ Yet the structuring of missiology is such that the aforementioned issues tend to fall under different missiological umbrellas, all with various foci.

Issues of race and racism, for example, tend to fall under the heading of reconciliation. Robert Schreiter's $(1992 ; 1998)$ work has been instrumental in conversations on reconciliation from a missional perspective. He acknowledges the African American context; however, he seeks to deal with reconciliation from a global, post-war, or at least post-violence, perspective. ${ }^{6}$ Looking at the global landscape of reconciliation, Schreiter identifies three major types of violence that have created a need for reconciliation (1992); one of which deals with racism and colonialism. As an attempt at providing strategies and scriptural bases for reconciliation globally, Schreiter highlights communism, governmental changes in Eastern Europe, the closing of China, and drastic regime changes in Chile. His work is helpful; however, it does not include the elements of the African American context specifically. The United States has recently experienced an increase in the filmed and sanctioned murders of Black bodies by law enforcement. Protest movements like Black Lives Matter have been joined by Black athletes in the NBA and the NFL, bringing attention to this particular violence and mobilizing communities for systemic change. It can be argued, then, that the United States is not yet in a post-violence context that would facilitate the implementation of Schreiter's thesis.

4 This has been evidenced by personal experience; the experiences of various colleagues, professors, and missiology faculty of various institutions; the list of authors contributing to missional journals, and even online searches of missiology syllabi, as described in the introduction.

5 See James Cone (1970; 1975), W.E.B. DuBois (2004), Langston Hughes (1990), Cornel West (2002), and others who highlight the particular plight of African Americans.

6 Unless otherwise stated, the context for this paper is the United States of America. Hence, terms like North American or American are used as shorthand for the US. No indifference to Central American or South American contexts is inferred or intended. 
As a missiological category, however, reconciliation seems fixated on interreligious dialogue. The work done by Jabbur (2008), Katerregga and Shenk (1997), and King, Tan, Dyrness, and Syeed-Miller (2014) show the major trend of scholarship with regard to reconciliation. This fixation on interreligious dialogue and the reconciliation of nations pushes the North American context of race out of the spotlight. Even the January 2019 issue of Missiology: An International Review (Starcher 2019) was focused on interreligious friendships, as was the June 2018 national meeting. Interreligious dialogue is a worthy focus, even inside the African American community. Black Americans have dealt with religious diversity, postmodernity, pluralism, and ecumenism for some time; particularly since the 196os in the United States. From the Nation of Islam, African Spirituality, Hebrew Israelites, Black Power, Buddhism, Vodun, Native Mythology, Catholicism, and every form of Protestantism available, African American communities have a history of engaging with interreligious dialogue. However, the prevalence of race as a social construct in the world - one in which darkness is nearly universally akin to sin, shame, and inferiority - is a reality that must not be sacrificed on the altar of interreligious dialogue. ${ }^{7}$ Making such a sacrifice would be to ignore the work of leading African American scholars like Brenda Salter McNeil (2016), Drew Hart (2016), and J. Deotis Roberts (2005), who have made major contributions to racial reconciliation, but whose works go unlisted in missiological syllabi. McNeil's contributions toward helping churches navigate racial reconciliation are foundational. McNeil carefully navigates the definition of the term "reconciliation," recognizing that some find the very term problematic because there has never been - in the context of the United States of America - a time of "conciliatory relationship" to begin with (2016:20). This necessary work done by McNeil is ignored or muted in missiological conversations.

Similar to race, issues of poverty tend to be subsumed under the umbrella of development (see Christian 1999; Myers 2011, and others) and largely focus on global poverty, often to the exclusion of urban, North American poverty. Poverty is not unique to the African American experience, yet the African American experience has unique qualities that are not often addressed in projects of rural development. Marred identity and the global implications of poverty discussed by Christian and Myers are applicable in the African American context. However, the particularities of White Nationalism, chattel slavery, Jim Crowism, segregation, the industrial prison complex, bi-partisan political

7 Michael Lee speaks to this in "Interdisciplinary Reflections on the Resilience of Racial Constructs" (2016), although it is not written from an African American perspective. 
jockeying, and government-sponsored drug introduction and eradication need to be part of conversations regarding poverty in the African American context. ${ }^{8}$

In the same vein, themes of contextualization and cross-cultural engagement are outsourced. The focus of cross-cultural engagement is rarely on immediate American contexts. Rather, the gaze centers on communities primarily in Asia and Africa (see Shaw 2010; Walls 2002, and others). African perspectives are present in missiology (see Hanciles 2008; Katongole 2017, and others), yet they very rarely express an explicitly African American experience, which clearly presents a separate list of issues and concerns. ${ }^{9}$ The focus is often on particular phenomena in African contexts or the reversal in the direction of mission to North America. Again, there is a conspicuous absence of African American voices. Walls' (2002) intercontinental approach to explaining the cross-cultural diffusion of the gospel demands attention to "Africa" and "the West" at large. Walls' extensive time on the continent of Africa informs his necessary contributions, but cannot be accepted as a substitution for indigenous African voices..$^{10}$ In either case, the specificities of the African American context are not included in these approaches to contextualization and cross-cultural engagement. Further, the narrative is not provided by an African American voice. As a result, the robust knowledge that could be gained from the African American experience of navigating the pluralism mentioned previously is neither heard nor valued as a source or resource for missional conversation regarding cross-cultural engagement.

In this essay, I am not arguing for missiological conversations on poverty to focus solely on the plight of African Americans. Rather, I am advocating for missiological inclusion. This inclusion is all the more necessary when one considers that poverty in the African American context (and others as well) includes issues of justice, identity, and urban spaces. These concepts are sometimes missing from conversations about global poverty and development, as previously described. Groody's, Globalization, Spirituality, and Justice (2015) addresses justice, yet it is not specifically intended to deal with the core of systemic injustice the way Brenda Salter McNeil (2016) does.

8 See Michelle Alexander (2010), Dominique Gilliard (2018), Ava DuVernay (2016), Goran Olsson (2011), and Cornel West (1993).

9 Hanciles (2008) does deal with some of the perspectives and issues within the African American community, yet not as a focus of his work. Hanciles' engagement of the African American context is framed around how African immigrants in the US engage with African Americans. Summarily, Hanciles can be seen as one of the few contributors, but the clear focus of his work should be noted.

Walls will also be used later to highlight his own understanding of this very issue. 
Finally, inner-city and urban concerns in North American missiology are placed under the missiological jurisdiction of urban missiology, which is championed by White and non-African American voices (see Bolger 2012; Conn 1987; Conn and Ortiz 2010; Gibbs and Bolger 2005; Van Engen and Tiersma 1994, and others). With no disregard for the valuable work done by these scholars from their particular contexts, something is missing overall in the field. These works may deal with some African American contexts, but the voices are very rarely African American. To be fair, the works edited by Bolger and Tiersma-Watson both contain chapters written from specifically African American contexts and by African American authors.

Is this enough? Can the discipline say with integrity that the existing dearth of African American missiology can be pacified by a few chapter contributions in books edited and compiled by White scholars, sporadic honorable mentions in works focused on other endeavors, and the few African American missiologists who dare to identify with the discipline?11 To answer with anything but a resounding negative is to be blinded by the exact conditions present in the African American context - marginalization and lack of self-representation. The present predicament is akin to what Carter G. Woodson describes as a false "interracial cooperation" (2017:14). Woodson explains that any time African Americans are not involved in the decision-making and operational roles of educational processes that involve or educate African Americans, it is not actual cooperation. It is merely the dominant culture carrying out its demands. This operation is usually done by acknowledging or involving a few African Americans, but the power to control processes and narratives clearly rests with the dominate group. In this type of process, Woodson contends, the African Americans are "cooing," and Whites are "operating" (2017:14). The product of marginalization - not just in the American context - is that the marginalized community experiences a forced exterior representation that is then validated by minimal representation. This is, indeed, not enough.

To suggest otherwise is to deny the problematic history of race and racism in the United States and the historical intertwining of mission and colonialism. Even the renowned scholar and mystic Howard Thurman contributed to this conversation in the 1940s, contending that mission has historically been hijacked and made an "instrument of self-righteousness on the one hand and racial superiority on the other" (1996:2-3). The racial construct being described here is one in which darkness is nearly universally akin to sin, shame,

11 See the work of Marsha Snulligan-Haney (Snulligan-Haney and Peters 2006; Snulligan-Haney 2007) and Daniel White Hodge (2007; 2013; 2018). 
and inferiority, and whiteness is seen as ideal. ${ }^{12}$ Black bodies, in this racialized American context, do not have the same inherent value as White bodies (Douglas 2005; hooks 1992; Tisby 2019). Blackness is seen as a lesser status and a hindrance to higher thought. James Evans argues, "People of African descent in Europe and North America have not been able to address the question of what it means to be human without, first, wrestling with what it means to be black" (Evans 2012:99).

These reasons support the contention that African American voices need to be welcomed and highlighted missiologically. However, missiology proper has, subconsciously or not, outsourced many of the individual aspects of the African American experience to other missiological umbrellas and non-African American voices. Subsequently, the discipline seems to be able to get by largely without having to address African American culture or its voice specifically. In fact, one has to go back to 2013 to find an article in Missiology: An International Review that is decidedly African American in scope and context. ${ }^{13}$ To use the language of Robert Hood (1990), the sum of these actions can make the African American missiology scholar feel "homeless" when engaging the corpus of the discipline.

While all of the aforementioned missiological foci of reconciliation, poverty, contextualization, and urban mission are important and need to be addressed, it seems that the current engagement is being done at the expense of the African American voice. This is not simply an argument for the particular in opposition to the universal. Rather, the argument being espoused is that the particular can inform the universal. As stated above, race as a social construct is prevalent in the North American context, and it is frequently monopolized by a White-Black binary. ${ }^{14}$ We cannot, then, abandon a discussion of race within missiology when we are - at the core - still having a conversation about the imago Dei and value of bodies of all colors and phenotypes.

Without a single focus for the discipline, each missiologist, school, or convention is left to determine the impetus and epistemology of the discipline. Those who feel missiology is inherently a theological enterprise will lean

12 To see this racial-moral representation engaged beyond the context of the United States, see Smith et al., Churches, Blackness, and Contested Multiculturalism: Europe, Africa, and North America (2014).

13 See Daniel White Hodge (2013). In the interest of full disclosure, there are a couple of book reviews in that time that were written by African American scholars Luisa Gallagher (2017) and Ruthie Johnson (2016). Outside of the contributions of Gallagher and Johnson, there is a void of honest engagement with texts that speak to African American contexts.

14 It is somewhat beyond the scope of this brief essay, but the presence and operation of race globally is also an issue. 
towards theological scholars. They will tend to eschew the voices of social scientists and practitioners. Those who feel missiology is fundamentally about equipping missionaries and mission organizations will, conversely, tend to avoid theological scholarship in favor of works by practitioners. When this is done, African American scholars left in the wake of the missiological boat are covered in dual waves. They are ignored both because of their ethnic particularity and their scholarly focus. Add to this the fact that the assumed "sending nature of God" present in many Trinitarian missiologies has a built-in bias in the context of the United States of America. This is too large a concept to unpack completely in a few sentences; however, a statement or two is necessary here to establish the background for the preceding statement on Trinitarian missiology.

I contend that part of the root cause for the dearth of African American voices in missiology is a view of mission based on a "sending nature" of God (Sunquist 2013). While there is biblical license for this position, an incarnational foundation of mission seems to be more consistent with the totality of what God has revealed in scripture about God's self - namely that God created and is present with humanity. Beginning with God's presence in the Garden and continuing through to the pinnacle expression of God's presence in the Immanuel - God with us - one can see God's emphasis on being present with God's creation. Additionally, an incarnational foundation also prevents the assumption that mission is primarily an action of being sent from a particular location to a particular location. The action of sending often allows people to ignore communities and populations who are proximate to their existing location for the sake of traveling to remote locations to "do mission."

I am hardly the first to acknowledge structural issues in the discipline. Back in the late gos, Andrew Walls was already noticing that "The root of many of our structural problems in mission studies lies in the relationships of mission studies to the rest of the world of learning" (1996:149). He saw issues in the discipline more than twenty years ago. In fact, he devoted an entire chapter to unpacking what he called the "Structural Problems in Mission Studies." He advocated for theology as the primary conversation partner but wholly acknowledged:

Our theological institutions taken alone do not have the resources within themselves to effect the needed renaissance. Mission studies must interact with ongoing work in the history, languages, political, economic and social organization, cultures, and literature of the Southern continents (not to mention many aspects of the Northern).

1996:52 
Walls goes on to list social sciences and history of religion as specific disciplines, along with theology, that need to be engaged robustly by mission studies. These are the exact disciplines this essay is advocating for, which are often included in missiology, except when it pertains to the African American context. Since Walls' publication, the work of engaging other disciplines has been robust. However, the lack of engagement with African American scholarship in those same fields remains conspicuously absent.

\section{$2 \quad$ Existing Catalogue}

The second factor under consideration is a contention that there is already an existing corpus of texts written by African American scholars that have not been widely accepted as missiological. As I discuss this existing African American catalogue, I will refer to works as being either missiological in nature or missiological in scope. To say a work is missiological in nature means that the work is dealing conspicuously with missiological themes and engaging missiological vernacular. On the other hand, a text that is missiological in scope does not set out to discuss mission but, based upon the interdisciplinary praxis of the field, should be included.

While many texts that take on specific issues, ideas, or trends are accepted as missiological, the same latitude is often withheld from African American scholarship. For instance, Charles Kraft's widely used Communication Theory for Christian Witness (1991) deals specifically with communication and meaning as it pertains to the Gospel. The actual term "missiology" is absent from the text, and the term "mission" is also alarmingly scarce. Yet this text is widely accepted for its missiological significance and importance. Will Coleman addresses very similar issues in Tribal Talk (200o). Coleman looks at traditional African spirituality, slave narratives, and Black theology. He discusses the interpretive process necessary to evaluate African oral traditions. Robert Hood undertakes a similar project in Must God Remain Greek? (1990). Hood analyzes indigenous African theologies in comparison with a Graeco-Roman controlled worldview and theology.

Both Coleman and Hood are missiological in scope. Neither sets out to center their work around the mission of God; rather, like Kraft, they look heavily at language, receptors, meaning, oral traditions, interpretation, and the theological implications of communication. ${ }^{15}$ However, neither Coleman nor Hood

15 This is not to say that the agendas of Coleman and Hood are synonymous to Kraft. The latter is obviously pushing for a type of communication that fits the preaching of the 
are included in missiological conversations. One could argue that the siloed nature of academic disciplines causes great voices to be missed because their work does not specifically address a discipline's target audience. The rebuttal to this claim, however, is that missiology claims to be interdisciplinary at its core. Disciplines like theology, anthropology, history, and communications are constantly engaged and mined for work that intersects the complicated and evolving understanding of mission.

Marsha Snulligan-Haney, a mission studies scholar, writes from a decidedly missiological perspective. Snulligan-Haney has published two works that deal with missiology, mission, and evangelism from an African American perspective: Evangelism Among African American Presbyterians (2007), and Africentric Approaches to Christian Ministry (Snulligan-Haney and Peters 2006). Her work is explicitly missiological in nature, yet she does not rely upon the normative missiological voices often found in - and dominating - the American context such as David Bosch, Lesslie Newbigin, or Andrew Walls. ${ }^{16}$ In her publications, Snulligan-Haney builds upon scholars like Gayraud Wilmore, Cain Hope Felder, Katie Canon, and C. Eric Lincoln. This is key for Snulligan-Haney as an African American missiologist - and for future African American scholars in the field - because she disrupts the normative, White, American and European starting points for missiological conversation found in the US. By grounding her missiological efforts in the works of those who have not been previously considered missiologists, she is speaking to the discipline and providing a much-needed corrective to the Woodson concept of "cooperation" discussed above.

In her co-edited volume(Snulligan-Haney and Peters 2006), Snulligan-Haney sets out to describe an Africentric missiological pathway. ${ }^{17}$ She stresses the need for a lively interaction between the gospel and culture, and posits that an African American approach can help to expose colonial presuppositions in scholarship. Her approach, like this essay, utilizes the particular to speak to the universal. The scholars upon whom Snulligan-Haney builds were not

gospel, with implications towards mission. I am asserting that Kraft is given the privilege of inclusion and latitude whereas Coleman and Hood are not even acknowledged.

16 The scholars listed represent some of the "standard" missiological texts in the United States. While there are indeed other, diverse authors that can be added to such a list, the fact remains that the most uniform voices found in American missiological syllabi are White males.

17 Snulligan-Haney uses the term Africentric but, as the subtitle of the book reveals, she is still dealing with the African American perspective. This could be helpful for some readers, or seen as the problematic muting of Black, non-American voices - as Reid-Salmon (2008) contended. 
considered to have anything of value to contribute to the missiological endeavor; hence, their absence from missiological syllabi, publications, and curricula. Snulligan-Haney is able to mine these existing works and highlight the missiological content and implications that are already present. ${ }^{18}$ In doing this work, Snulligan-Haney assists the larger missiological audience to hear from voices that engage missiological content, yet are often absent from those conversations. This is the point of both this paper and, in particular, this section missiology needs more specifically African American voices to translate and highlight the missiological content of existing African American scholarship.

Gayraud Wilmore's work is, in many ways, another untapped missiological goldmine. Black Religion and Black Radicalism (1998) engages the missional activity of the Black church, the major denominations, and key individuals. Terms like syncretism, contextualization, and mission may be missing from the index, but this should not preclude acknowledging and highlighting the missiological themes in his work. Wilmore speaks of contextualization directly when he says, "It became the blacks' purpose - perhaps destiny - to shape, to fashion, to re-create the religion offered them by the Christian slavemaster, to remold it nearer to their own heart's desire, nearer to their own peculiar needs" (1998:vii). Further, "It was from within an African religious framework that the slaves made adjustments to Christianity after hearing the gospel" (1998:50). Wilmore is describing, at length, theory and practice that is identical to what acclaimed US missiologists Gilliland (1989) and Bevans (1992) articulate. All three - Wilmore, Gilliland, and Bevans - are communicating the process in, dangers of, and need for contextualization. The work that Wilmore records pre-dates the academic exercises of defining and re-defining contextualization for contemporary missions, with an account that is a historical record of how African Americans were engaged in theory and praxis centuries prior to the academic venture. Wilmore's work is absolutely missiological in scope, and an argument can be made that it should be viewed as missiological in nature.

Wilmore's case is not an anomaly. In Troubling Biblical Waters (1989), Cain Hope Felder makes comparable statements. Felder points to the theological and missional thinking of African American clergy and denominations. C. Eric Lincoln (Lincoln 1974; Lincoln and Mamiya 1990) also details this process of the formation of a truly unique African American faith. This is the

18 Snulligan-Haney need not re-interpret their work - which would imply a lack of missiological content in the original work. Rather, she re-presents - presenting the existing work to a new audience for consideration; or perhaps even re-consideration. This process may require equipping the discipline with terminology and framework necessary to recognize missiological contributions outside of normative contexts. However, the process is often merely highlighting missiological content and terminology already present. 
same process about which Andrew Walls (2002) and Lamin Sanneh (2009) speak - even if the jargon is different. As vital as the contributions have been from Sanneh and Walls - whom I use in my own research - scholars like Will Coleman and Robert Hood (as cited previously) were having these same conversations about releasing Christianity from the moorings of European domination in thought and expression. Hood even uses language of syncretism, contextualization, and indigenization. ${ }^{19}$ Yet these authors rarely see the light in missiological conversation, publication, or education. Meanwhile they are, perhaps, the exact manifestation of what Walls was calling for.

In the arena of Black theology, there have been powerful voices that also deal with missiological concepts like translation, reconciliation, and the meaning of the church. Frederick Ware (2002) addresses issues of translation and reconciliation, which he sees as fundamental to the exercise of putting forth a Black theology. James Evans (2012) traces the roots of African American faith as well. He demonstrates that the existing Christian faith and practice of African Americans - and Black theology - is heavily rooted in a critically contextualized merging of American Protestantism and African spirituality. As with other works dealing with Black theology, there is an emphasis placed on the Black experience - on the existential realities, history, cultural norms, and products. ${ }^{20}$ These emphases are at the core of cultural anthropology as well as missional work and theory. This is not unlike Shaw's work of grounding mission inside the very context of a culture (2010). Shaw and Ware would agree that any theological or missiological work must be done with the Incarnation in mind. ${ }^{21}$

Black theology has continued to push for recognizing Jesus' identity as God's Immanuel with the oppressed. Shaw stresses that the missional application of the Incarnation means to live the gospel "within" a context as opposed to preaching the gospel "to" a context" (2010; 211), and Ware (2002) actually defines Black theology as an act of interpretation. ${ }^{22}$ They are both speaking of the activity highlighted by Arthur Glasser in Old Testament Contextualization; that its core, contextualization, is pushing for an exploration of the "legitimate demands the gospel makes within any specific cultural situation by virtue of its inherent nature as holistic - the incarnational Word of God - embracing as it does the existential totality of human need" (1989:32-33).

19 Coleman, like Shaw, is demystifying the spirituality and practice of a culture and presenting an indigenous hermeneutic.

$20 \quad$ For examples, see Cone (1970; 1997), Hopkins (1993), Mitchell (1990), and LaRue (2000).

21 See the concluding remarks in the previous section.

22 Again, we see major similarity in the language of Ware and noted missiologists like Sanneh and Walls. 
The work done by this catalogue of African American voices not only strives to affirm the humanity of people of African descent but also stresses their need to write their own stories. This section does not attempt to determine whether all of the aforementioned works (and others not noted) should be automatically received as missiological publications or as missiological in nature. Many of these authors are very clear in describing the goal of their work, whether it be setting out theology, writing history, or describing the act of preaching. They are all, however, missiological in scope.

In this essay, I am contending that there are significant missiological components to many of these works, which have been overlooked by the discipline. Missiology is multi-disciplinary in nature, and it usually encompasses communication, history, and culture. This is not so, however, when it comes to the African American voice and scholar. Further, some of the works mentioned are expressly missiological in nature. C. Eric Lincoln includes descriptions of missional societies and efforts of the various Black denominations and movements (Lincoln and Mamiya 1990), as does Haney (2007). Robert Hood (1990) uses missiological language. Wilmore's work (1998) is decidedly about the missional activity of the African American church, much in the same vein as Sunquist's work (2013). ${ }^{23}$ Nevertheless, they are not generally included in the reading lists for courses in missiology.

\section{A Black-ish Missiology}

Using the idiomatic expression found in the United States, this essay has contended that the current field of missiology is black-ish. The expression is used to describe something that purports to be Black (African American), but upon close inspection may not be authentic to, or representative of, the culture. The bulk of this essay has been dedicated to the work of description and diagnosis. The subtlety of the title is more descriptive than prescriptive. It is a jab at the conclusion that dealing with some of the characteristics of African American life without dealing with or hearing from the exact context makes missiology as it is currently construed, black-ish; meaning it is close to Black but not Black. To say that missiology is black-ish is to say that the discipline is close enough to the Black experience to talk about portions of that experience, but far enough

23 Just as Sunquist recounts the history of Christian movement and thought with an eye on participation in suffering, Wilmore recounts the history of the African American Christian movement with an eye on Black radicalism and adaptation. More, Wilmore's work is also published by Orbis. 
that the discipline has not been truly touched, challenged, or changed by the Black experience. To say that missiology is black-ish is to say that the African American context has not been afforded space and voice to address the particular context and experiences of African Americans. At present, missiology lacks a robust core of African American missiologists. Further, the discipline has subsumed - or outsourced - the African American experience, leaving non-African American scholars to speak to the African American context.

Thus far, then, this essay has critiqued missiology as being black-ish. However, in an essay like this, I would be remiss if I did not at least provide some framework for beginning an authentically Black missiology, that is, a missiology done from and for a specifically African American context. ${ }^{24}$ To this end, I assert that a Black missiology must do three things.

First, a Black missiology must be rooted in the Incarnation and not in a perceived sending nature of God. To begin, the presence of God with God's people is a hallmark of Black theology. Womanist and Black theologians rely heavily on the Black experience as a theological norm. ${ }^{25}$ This process - or hermeneutic - of doing theology and interpreting scripture from the particular context of the Black experience dates back, at least, to the seventeenth century (Wilmore 1998). It was not until the work of James Cone and others in the 196os that the Black experience was taken seriously as a starting point for theology in the United States. Kelly Brown Douglas (2005:163) insists, however, that it was a hermeneutic of appropriation that allowed African Americans to, early on, adopt and fashion Christianity when the Bible and religious practice were seen as speaking to the realities of Black life.

Cone (2010) held firmly that any Black theology must start from the reality of Black existence. Using the work of Tillich (1967), Cone built a systematic theology from the African American context. ${ }^{26}$ In short, Cone helped to cement the Black experience as a theological source. Even the National Committee of Negro Churchmen, which preceded Cone's publications, grounded their

24 This brief work can only hint toward the construction of a Black missiology, and the work here does not purport to speak for the entire complexity of the Black experience in the United States of America. Nor can it speak on behalf of other Black missiological contexts (e.g. Afro-Caribbean, Afro-Latina/o, or African). This work builds upon the foundations of all of the scholars previously mentioned.

25 As used in this article, the term "Black experience" should be understood as the totality and diversity of experiences encountered by people of African descent in North America, typically from the perspective of the struggle for liberation. This definition is consistent with the work of bell hooks (1992), James Cone (1975; 2010), and Cornel West (2002). It is not, however, exclusive of African diasporic immigrant communities in America.

26 Cone (2010) contends that all theology is contextual as it is ultimately human language about the divine. 
movement in "Scripture and the Black religious experience" (Wilmore 1998:242). The inclusion of the Black experience as a source for doing theology has played a major role in the development of Black Christian faith, and in subsequent generations of Womanist and Black theologians. ${ }^{27}$

The perceived sending nature of God is, as stated, a perception or interpretation. God has specifically stated and shown, however, that God desires to be present with humanity. While no one can argue that Jesus was sent into this world or that the Holy Spirit is sent, some clarity is necessary. Jesus states plainly that he was sent $(\dot{\alpha} \pi \circ \sigma \tau \dot{\varepsilon} \lambda \lambda \omega)$ from the Father (Matt. 10:40; 15:24; Luke 4:18), and that he, in turn, sent out the disciples (Matt. 10:5; Luke 9:2). The conclusion, however, that God is a sending God by nature is based more heavily on an understanding of divine activity than on the majority content of divine revelation in scripture. Again, while Jesus does reveal that he was "sent" by God, that is hardly all that he says about himself, nor all that God reveals about him.

There is actually another characteristic of God that is revealed in Scripture with much more frequency, intensity, and consistency than the idea of a sending nature. God has self-revealed that God is "present" throughout all of Scripture - not just the New Testament. ${ }^{28}$ From the presence of God in the Garden to the impending New Heaven and New Earth built around God's presence on the throne, we see God revealing a desire to be present with humanity and for humanity to be present with God. Yes, we can reasonably and theologically conclude that there is a "sending" nature to the triune God, but what God says and self-reveals seem to be far more focused on impressing upon humanity the fact that God wants to be present with us.

From the beginning of scripture, God creates humankind in the imago Dei and breathes divine breath into humanity, showing the original design for humanity to be bearers of God's presence. Throughout humanity's repeated failures, God strives to be present and to be "their God." The pinnacle of God's presence with humanity is expressed in the Incarnation. Of great import is

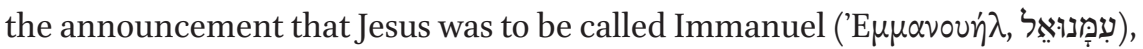
God with us (Matt. 1; Isa. 7). Additionally, our Christian eschatology, no matter how varied, centers on eternal communion with God in God's presence. Hence, God's presence with us seems to be much more prevalent in what God has self-revealed than a sending nature. To further complicate things, in some cultural understandings, the terminology of sent, when applied to God, may

27 See also the work of Hopkins (1993), Canon (1995), and Ware (2002).

28 See Josh. 1:9; Deut. 31:6; Isa. 41:10; Ezek. 48:35; Ps. 23; 139; Rev. 3:20; and, of course, Matt. 28. 
convey an image of deism. ${ }^{29}$ Athanasius warns against such a view, stressing that even prior to the Incarnation, God and God's Word were not far from creation but ever part of it (2013:16). Again, we see emphasis on the presence and nearness of God.

An American missiology, then, that is rooted in a solely sending God allows us to send missionaries to parts of Africa but ignore the incarnational obligation to be present with African Americans in our nation and community. A Black missiology must take seriously the fact that God became flesh and "moved into the neighborhood." (John 1:14 MSG). An incarnational foundation recognizes the socio-cultural location of Jewish Jesus in a Roman world. Yet this particularity, as Kwame Bediako (2004) expresses, does not negate the universality of Jesus. Bediako urges that Jesus is the savior for all people and that the Incarnation and Christianity, must be viewed in the cultural context. This incarnational foundation forces mission to be about presence, not just sending. The Incarnation is also foundational for Black and Womanist theology, as detailed above.

The second pillar of a Black missiology is that this missiology must assert its own voice. This assertion challenges the discipline to unseat the normativity of the dominant culture and dominant trends in order for all voices to speak and be heard. If Cone is correct that all theology is contextual - and I believe he is then wouldn't missiology also be contextual for similar reasons? Ultimately, missiology is about the theology or the practice of mission - depending, again, on which way the discipline is being directed. If this relies heavily on human language and methodology, then it should also be confessed that missiology is very much contextual as well. Perhaps Bosch (1991) or Bevans and Schroeder (2004) best exemplify the contextual nature of missiology. However, missiology cannot allow current categorizations within the discipline to rob the African American experience from its individual components, nor can it allow contextual understandings of the impetus or content to monopolize the totality of the focus. Asserting the African American voice means affirming the particularities of the Black experience in the United States. Asserting the African American voice also means hearing other ways of discerning and understanding the activity of God in the world. When done, it also leads to interpreting existing texts so that the missiological and missional fruit may be shared with the universal Body of Christ and used to inform the guild. This assertion is the validation of the imago Dei in Black lives, and the recognition of the missio Dei in Black communities.

29 In that God stands apart from or distant from creation and, hence, must "send" Jesus or the Spirit. 
The assertion of the African American voice in missiology is an admission by the discipline that there is a void that needs to be filled. Missiology, like theology and anthropology before it, needs this course correction. Missiology needs to be reminded that the particular experiences of communities come to bear on academic theory and missional praxis. These particular experiences lead us to new ideas, fresh concepts, and innovative ways of engaging God's mission. Without them, both academic and missional ventures are incomplete.

Third, a Black missiology must be global. The end goal for a Black missiology is not simply to affirm the African American experience alone. There are global ramifications for hearing and not hearing the African American experience. One need only look at the global impact of Hip Hop culture in Korea, Japan, Ghana, Nigeria, and Cuba to see that a Black missiology, borne out of a particular African American context, has global implications (Basu and Lemelle 2006; Dixon 2015; Terkourafi 2010). Dwayne Dixon (2015) outlines the parallels between the socioeconomic conditions and familial structures of Japanese youth near the turn of the century and Black youth in the US in the 1970s. Dixon shows how the particularities of the African American experience connected deeply with Japanese youth, and both engaged Hip Hop culture as a way of voicing protest against systemic dangers and injustice. Whether the focus is on the immigrant Hip Hop culture in Germany or in South Korea (Terkourafi 2010), the model is the same. Various local communities around the globe find deep connection with Hip Hop - a distinctly Black, urban, North American product (Hodge 2010; Watkins 2011). This is the potential of a Black missiology.

Summary

This essay has attempted to highlight the lack of African American contributions to the field of missiology, while also drawing attention to a few key African American voices. It is the contention of this essay that several major factors have contributed to this overall dearth. The structuring of the discipline and lack of universal direction have proven problematic for African American voices and concerns to gain footing. Particularities of the Black experience in the United States have been outsourced to numerous missiological categories in which non-African American voices and contexts reign supreme. This essay has also tried to demonstrate the inherent blind spots of a missiology that is solely Trinitarian in nature - not considering the importance of the Incarnation and God's repeatedly expressed desire to be present with humanity. When all of this is placed in conversation with the lack of African American 
missiologists and the colonial history of mission, the absence of Black voices is palpable.

I have tried to give some prescriptive attention to how we may go about constructing a missiology that is authentically Black and not merely black-ish. A Black missiology must be incarnational, it must assert the African American voice, and it must be a local product that has global implications.

To close this essay, consider a point of inclusion. If a major publication for missiology in the USA is able to find space to discuss Catholicism, political intelligence, Anglicanism, Islam, interreligious dialogue, post-Christendom, displacement, East Asian theology, intercultural theology, leadership, Christology, syncretism, religious education, ecclesiology, and even missionaries and social media, then surely there is room to discuss a Black missiology. The mission of the church is blessed and expanded when we hear all these voices. The African American voice cannot be muted for the sake of another. It must be included for the sake of all.

\section{References Cited}

Alexander, Michelle. 2010. The New Jim Crow: Mass Incarceration in the Age of Colorblindness. New York, NY: New Press.

Athanasius. 2013. On the Incarnation. Fig.

Basu, Dipannita, and Sidney J. Lemelle, eds. 20o6. The Vinyl Ain't Final: Hip Hop and the Globalization of Black Popular Culture. London: Pluto Press.

Beckford, Robert. 20oo. Dread and Pentecostal:A Political Theology for the Black Church in Britain. Eugene, OR: Wipf \& Stock.

Bediako, Kwame. 2004. Jesus and the Gospel in Africa: History and Experience. New York, NY: Orbis.

Bevans, Stephen B. 1992. Models of Contextual Theology. Maryknoll, NY: Orbis Books.

Bevans, Stephen B., and Roger Schroeder. 2004. Constants in Context: A Theology of Mission for Today. Maryknoll, NY: Orbis Books.

Bolger, Ryan K. 2012. The Gospel after Christendom: New Voices, New Cultures, New Expressions. Grand Rapids, MI: Baker Academic.

Bosch, David J. 1991. Transforming Mission: Paradigm Shifts in Theology of Mission. Maryknoll, NY: Orbis Books.

Cannon, Katie G. 1995. Katie's Canon: Womanism and the Soul of the Black Community. New York, NY: Continuum.

Carter, J. Cameron. 2008. Race: A Theological Account. Oxford University Press.

Christian, Jayakumar. 1999. God of the Empty-Handed: Poverty, Power, and the Kingdom of God. Monrovia, CA.: MARC. 
Coleman, Will. 20oo. Tribal Talk: Black Theology, Hermeneutics, and African/American Ways of "Telling the Story." University Park, PA: Penn State.

Cone, James H. 1970. A Black Theology of Liberation. Philadelphia, PA: Lippincott.

Cone, James H. 1975. God of the Oppressed. New York, NY: Seabury Press.

Cone, James H. 1997. Black Theology and Black Power. Maryknoll, NY: Orbis Books.

Cone, James H. 2010. A Black Theology of Liberation. 4oth Anniversary. Maryknoll, NY: Orbis.

Conn, Harvie M. 1987. A Clarified Vision for Urban Mission: Dispelling the Urban Stereotypes. Grand Rapids, MI: Zondervan.

Conn, Harvie M., and Manuel Ortiz. 2010. Urban Ministry: The Kingdom, the City \& the People of God. Downers Grove, IL: IVP Academic.

Dixon, Dwayne. 2015. "Contextualizing Hip-Hop in Japan and Its Role in Youth Culture." East Asian Youth Cultures Spring 2015: Globalized Identities, Localized Practices, and Social Transitions. http://scalar.usc.edu/works/breakdancers-vocaloids-and-gamers -east-asian-youth-cultures-spring-2015/contextualization-of-hip-hop-in-japan.

Douglas, Kelly Brown. 2005. What's Faith Got to Do with It? Black Bodies/Christian Souls. Maryknoll, NY: Orbis Books.

DuBois, W.E.B. 2004. The Souls of Black Folk. Overland Park, KS: Digireads.

DuVernay, Ava. 2016. 13th. Netflix.

Erskine, Noel L. 1981. Decolonizing Theology: A Caribbean Perspective. Maryknoll, NY: Orbis.

Evans, James H. 2012. We Have Been Believers: An African American Systematic Theology. Minneapolis: Fortress.

Farrell, B. Hunter. 2018. "Re-Membering Missiology: An Invitation to an Activist Agenda." Missiology: An International Review 46 (1): 37-49.

Gallagher, Luisa J. 2017. "Book Review: Roadmap to Reconciliation: Moving Communities into Unity, Wholeness and Justice." Missiology: An International Review 45 (1): $128-29$.

Gibbs, Eddie, and Ryan K. Bolger. 2005. Emerging Churches: Creating Christian Community in Postmodern Cultures. Grand Rapids, MI: Baker Academic.

Gilliard, Dominique DuBois. 2018. Rethinking Incarceration: Advocating for Justice That Restores. Downers Grove: IVP Books.

Gilliland, Dean S., ed. 1989. The Word among Us: Contextualizing Theology for Mission Today. Dallas, TX: Word Publishing.

Glasser, Arthur F. 1989. "Old Testament Contextualization: Revelation and Its Environment." In The Word among Us: Contextualizing Theology for Mission Today, edited by Dean S. Gilliland, 32-51. Dallas, TX: Word Publishing.

Hanciles, Jehu. 2008. Beyond Christendom: Globalization, African Migration, and the Transformation of the West. Maryknoll, NY: Orbis Books. 
Hart, Drew G.I. 2016. Trouble I've Seen: Changing the Way the Church Views Racism. Harrisonburg, VA: Herald Press.

Hodge, Daniel White. 2007. Baptized in Dirty Water: The Missiological Gospel of Tupac Amaru Shakur.

Hodge, Daniel White. 2010. The Soul of Hip Hop: Rims, Timbs and a Cultural Theology. Downers Grove, IL: IVP Books.

Hodge, Daniel White. 2013. "No Church in the Wild: Hip Hop Theology and Mission." Missiology: An International Review Missiology: An International Review 41 (1): 97-109.

Hodge, Daniel White. 2018. Homeland Insecurity: A Hip Hip Missiology for the Post-Civil Rights Context. Downers Grove, IL: InterVarsity.

Hood, Robert E. 199o. Must God Remain Greek: Afro Cultures and God-Talk. Minneapolis, $\mathrm{MN}$ : Fortress Press.

Hooks, Bell. 1992. Black Looks: Race and Representation. Boston, MA: South End Press.

Hopkins, Dwight N. 1993. Shoes That Fit Our Feet: Sources for a Constructive Black Theology. Maryknoll, NY: Orbis.

Hughes, Langston. 1990. The Ways of White Folks: Stories. Reprint edition. New York: Vintage.

Jabbur, Nabil. 2008. The Crescent through the Eyes of the Cross: Insights from an Arab Christian. Colorado Springs, CO: NAv Press.

Jennings, Willie J. 2010. The Christian Imagination: Theology and the Origins of Race. New Haven, CT: Yale University Press.

Jennings, Willie J. 2017. "Race and the Educated Imagination: Outlining a Pedagogy of Belonging." Religious Education 112 (1): 58-65.

Johnson, Ruthie. 2016. "Book Review: Trouble I've Seen: Changing the Way the Church Views Racism." Missiology: An International Review 44 (3): 359-6o.

Kateregga, Badru D., and David W. Shenk. 1997. A Muslim and a Christian in Dialogue. Harrisonburg, VA: Herald Press.

Katongole, Emmanuel. 2017. "Field Hospital: HEAL Africa and the Politics of Compassion in Eastern Congo." Missiology 45 (1): 25-37.

King, Roberta Rose, Sooi Ling Tan, William A. Dyrness, and Najeeba Syeed-Miller, eds. 2014. (Un)Common Sounds: Songs of Peace and Reconciliation among Muslims and Christians. Eugene, OR: Cascade.

Kraft, Charles H. 1991. Communication Theory for Christian Witness. Maryknoll, NY: Orbis Books.

LaRue, Cleophus James. 200o. The Heart of Black Preaching. Louisville, KY:Westminster John Knox.

Lee, Michael Hakmin. 2016. "Interdisciplinary Reflections on the Resilience of Racial Constructs.” Missiology 44 (2): 194-206. 
Lincoln, C. Eric. 1974. The Black Experience in Religion. Garden City, NY: Anchor Press. Lincoln, C. Eric, and Lawrence H. Mamiya. 1990. The Black Church in the AfricanAmerican Experience. Durham, NC: Duke University Press.

McNeil, Brenda Salter. 2016. Roadmap to Reconciliation: Moving Communities into Unity, Wholeness and Justice. Downers Grove, IL: InterVarsity.

Mitchell, Henry H. 199o. Black Preaching: The Recovery of a Powerful Art. Nashville, TN: Abingdon Press.

Myers, Bryant L. 2011. Walking with the Poor: Principles and Practices of Transformational Development. Revised and Expanded. Maryknoll, NY: Orbis Books.

Olsson, Goran. 2011. The Black Power Mixtape 1967-1975. Netflix.

Reddie, Anthony G. 20o6. Black Theology in Transatlantic Dialogue. New York: Palgrave Macmillan.

Reddie, Anthony G. 20o9. Is God Colour-Blind?: Insights from Black Theology for Christian Ministry. London: SPCK.

Reid-Salmon, Delroy A. 2008. "A Sin of Black Theology: The Omission of the Caribbean Diasporan." Black Theology: An International Journal 6 (2). https://doi.org/10.1558/ blth2oo8v6i2.154.

Roberts, J. Deotis. 2005. Liberation and Reconciliation: A Black Theology. 2nd ed. Louisville, KY: Westminster John Knox Press.

Sanneh, Lamin O. 2009. Translating the Message: The Missionary Impact on Culture. Rev Ed. Maryknoll, NY: Orbis Books.

Schreiter, Robert J. 1992. Reconciliation: Mission and Ministry in a Changing Social Order. Maryknoll, NY: Orbis.

Schreiter, Robert J. 1998. The Ministry of Reconciliation: Spirituality \& Strategies. Maryknoll, NY: Orbis.

Sechrest, Love L., Johnny Ramirez-Johnson, and Amos Yong. 2018. Can “White” People Be Saved?: Triangulating Race, Theology, and Mission. Downers Grove, IL: IVP Academic.

Shaw, Daniel. 2010. "Beyond Contextualization: Toward a Twenty-First-Century Model for Enabling Mission." International Bulletin of Missionary Research 34 (4): 208-15.

Shenk, Wilbert R. 2014. History of the American Society of Missiology, 1973-2013. Elkhart, IN: Institute of Mennonite Studies.

Skreslet, Stanley H. 2012. Comprehending Mission: The Questions, Methods, Themes, Problems, and Prospects of Missiology. Maryknoll, NY: Orbis Books.

Smith, R. Drew, William Ackah, and Anthony G. Reddie, eds. 2014. Churches, Blackness, and Contested Multiculturalism: Europe, Africa, and North America. New York: Palgrave MacMillan.

Snulligan-Haney, Marsha. 2007. Evangelism among African America Presbyterians. Lanham, MD: University Press of America. 
Snulligan-Haney, Marsha, and Ronald Edward. Peters, eds. 20o6. Africentric Approaches to Christian Ministry: Strengthening Urban Congregations in African American Communities. Lanham, Md.: University Press of America.

Starcher, Richard L. 2019. “Editor's Notes." Missiology: An International Review 47 (1): 5 . Sunquist, Scott W. 2013. Understanding Christian Mission: Participation in Suffering and Glory. Grand Rapids, MI: Baker Academic.

Terkourafi, Marina. 2010. The Languages of Global Hip-Hop. New York, NY: Continuum. Thurman, Howard. 1996. Jesus and the Disinherited. Reprint. Boston, MA: Beacon Press. Tillich, Paul. 1967. Systematic Theology. Vol. 1. 3 vols. Chicago, IL: University of Chicago. Tisby, Jemar. 2019. The Color of Compromise: The Truth About the American Church's Complicity in Racism. Grand Rapids, MI: Zondervan.

Van Engen, Charles, and Jude Tiersma, eds. 1994. God so Loves the City: Seeking a Theology for Urban Mission. Monrovia, CA: MARC.

Walls, Andrew F. 1996. The Missionary Movement in Christian History: Studies in the Transmission of Faith. Maryknoll, NY: Orbis Books.

Walls, Andrew F. 2002. The Cross-Cultural Process in Christian History: Studies in the Transmission and Appropriation of Faith. Maryknoll, NY: Orbis.

Ware, Frederick L. 2002. Methodologies of Black Theology. Eugene, OR: Wipf \& Stock. Watkins, Ralph Basui. 2011. Hip-Hop Redemption: Finding God in the Rhythm and the Rhyme. Grand Rapids, MI: Baker Academic.

West, Cornel. 1993. Race Matters. Boston: Beacon Press.

West, Cornel. 2002. Prophesy Deliverance!: An Afro-American Revolutionary Christianity. Anniversary Edition. Philadelphia, PA: Westminster.

Wilmore, Gayraud S. 1998. Black Religion and Black Radicalism: An Interpretation of the Religious History of Afro-American People. 3 rd ed. Maryknoll, NY: Orbis Books.

Woodson, Carter G. 2017. The Mis-Education of the Negro. Reprint. Suwanee, GA: 12th Media Services.

\section{摘要}

使用在美国发现的惯用语，本文认为当前的宣教领域是 “黑色的”。该表述 用于描述一些看起来是黑人 (非裔美国人) 的东西, 但经仔细检查可能不 是真实地对待这种文化。本文旨在探讨非裔美国人对宣教学贡献的缺乏。 有人提到内部结构和认识论的问题, 认为在宣教研究缺乏统一性的迷宫 中, 非裔美国人的声音和文化常常迷失了。此外, 现有的黑人奖学金目录 直接或间接地涉及到宣教, 但通常没有像美国提供的白人奖学金那样具有 包容性和审查性。 


\section{Resumen}

Este trabajo utiliza una expresión idiomática común en los Estados Unidos y sostiene que el campo actual de la misiología aparenta tener ciertas características negras. La expresión se utiliza para describir algo que pretende ser negro (afroamericano), pero que al examinarlo detenidamente no parece ser auténtico a la cultura. Este ensayo busca examinar la falta de contribuciones específicamente afroamericanas a la misiología. Se presentan cuestiones de estructuración interna y epistemología, y se argumenta que las voces y la cultura afroamericanas a menudo se pierden en este laberinto constituido por una falta de uniformidad dentro de la misiología. Además, existe un registro de publicaciones de académicos afroamericanos que se ocupa, directa e indirectamente, de la misión, pero que a menudo no se les da el mismo nivel de inclusión y reseña que los académicos blancos reciben en los Estados Unidos. 